\title{
Lectora inspire software development in the learning of pencak silat
}

\author{
Aref Vai $^{1, *}{ }^{\circledR}$, Fitri Agung Nanda ${ }^{2}$, Deny Pradana Saputro ${ }^{1}$, \\ Ramadi $^{1}$, Muhammad Imam Rahmatullah ${ }^{1}$ \\ Universitas Riau, Indonesia ${ }^{1}$ \\ Universitas Negeri Yogyakarta, Indonesia ${ }^{2}$
}

Received: 24 November 2020; Accepted 08 February 2021; Published 25 March 2021

Ed 2021; 6(1): 109-118

\begin{abstract}
Entering the 4.0 era, innovation and learning development are needed as well in the world of refereeing, development is intended to make it easier and help to reduce mistakes in leading matches. This study aims to develop lectora inspire which will be used in martial art refinement. This type of research is a research and development $(R \& D)$ research. The subjects of this study use a small scale with a total of 10 students from the Department of Physical Education, Health and Recreation, Faculty of Teacher Training and Education, Universitas Riau. Meanwhile, the analysis technique used in this research is descriptive quantitative. The results of the research on the development tools of lectora inspire on martial art refinement are good, this is explained from the results of the validation of the content/material aspects with an average score of 4.29 , the learning aspects are categorized as good with an average score of 4.34 , the programming aspects and the media aspects have good categories. From the results of small group trials conducted by 10 subjects, data are obtained and it is concluded that the Lectora Inspire application is in good category with an average score of 4.32 and is able to be applied in learning martial art refinement. These results are intended to make it easier and help to reduce errors in the referee's assignment when serving on a small scale. Based on the results of this study, it can be concluded that the development of learning media for refereeing martial art by utilizing lectora inspire is suitable for use as a medium in learning audio-visual based martial art on a small scale.
\end{abstract}

Keywords: Pencak silat; media; learning; lectora inspire

https://doi.org/10.25299/sportarea.2021.vol6(1).5895

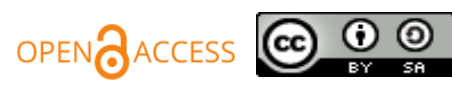

Copyright (C) 2021 Aref Vai, Fitri Agung Nanda, Deny Pradana Saputro, Ramadi, Muhammad Imam Rahmatullah

Corresponding author: Aref Vai, Physical Education Health and Recreation, Universitas Riau, Pekanbaru, Riau, Indonesia Email: aref.vai@lecturer.unri.ac.id

How To Cite: Vai, A., Nanda, F. A., Saputro, D. P., Ramadi, \& Rahmatullah, M. I. (2021). Lectora inspire software development in the learning of pencak silat. Journal Sport Area, 6(1), 109-118. https://doi.org/10.25299/sportarea.2021.vol6(1).5895

\section{INTRODUCTION}

Campus is one of the places for the transformation of knowledge and education in which there is a learning process. This learning process requires the development of a medium in order to create effective learning for each learning objective that is received. Therefore, of course, a lecturer needs to prepare the learning material that will be delivered and of course, besides that, he must also prepare appropriate learning media in order to accommodate the learning evaluation process of students. In learning, sometimes when students are not in accordance with a subject, they usually will not be interested in learning it (Saputro Masturi, \& Supriyadi, 2020). Therefore, a lecturer should be able do creation in creating an interesting leaning atmosphere. 
The learning process of educators is not just a pursuit in the traditional form. It is further revealed if a teacher must be able to follow the development of the era which has now entered the 4.0 era which requires learning by utilizing technology. The development of the current technological era known as the industry 4.0 revolution has a great impact on the job-specific changes that occur today. All work is always associated with the internet and technology. Technology makes learning more efficient (Hussin, 2018), these changes also have an impact on the world of education, where the learning process is not only face to face but also online (learning through the network) (Saputro et al., 2020). Likewise, in media development, educators are currently using technology in developing learning media. Era 4.0 plays an important role in developing technology (Doloksaribu \& Triwiyono, 2020). The ability of educators to implement the Industrial Revolution 4.0 has an impact on improving the quality of education and students both on improving cognitive, psychomotor and affective abilities. This is an effort in order to fulfill the duties and obligations of a lecturer as a sports and Health Physical Education educator, including as a regulator, guidance and advisor for participants. Regarding the teaching method, there are two components that need attention. Among them are teaching methods and learning media as teaching aids. This is made clear by that progress in the learning process is related to the activities of educators (Estheria \& Muhid, 2020).

Research result of Sardirman (2019) reveals if the learning device is used to clarify the presentation of the material so that it is not verbal. The types of learning tools are very different, according to Cecep and Bambang (2011) learning equipment consists of several types, including (1) print media, (2) audiovisual media, (3) computer-based technology media, (4) a combination of print media and information technology. Of the several types of media presented, learning activities can be maximized if combined with print media and information technology. This is needed in the hope that the learning process can run effectively.

In sports learning, there are many sports that can be studied, one of which is the sport of pencak silat. Pencak silat has many benefits that can be obtained by students such as cognitive, affective, and psychomotor development (Vai, Ramadi, Juita, \& Sulastio, 2019). Learning pencak silat is not just learning theoretically but it must also be taught in practice. In sports activities, Pencak Silat is combined with several elements of motion that support one another, including the value of art, as well as accentuating the beauty of movement (Iswana \& Siswantoyo, 2013). Rahmatullah (2019) states that the use of offline and online learning media must be implemented to keep up with the times.

Today, the rapid development of technology has an impact on various things in life, especially those relates to activities in education. Education with a combination of technology will facilitate the process of learning activities (Hariyoko, Hariyanto, \& Kurniawan, 2018), and lighten the learning process by using the media. It is also hoped that it can increase the enthusiasm for learning for students when the learning process takes place, this also happens in learning Pencak Silat.

However, if the author looks back on the Pencak Silat learning research model that has been done before, the application used to create this IT-based learning model requires people who are experts in their fields. Creation of the appearance and content of the application needs to be consulted again with IT experts. This has resulted in less effective and efficient media creation activities. Therefore, other equipment is needed that can make it easier for teachers to make interactive learning media. Research with the title Lectora Inspire Interactive Learning Media as a Learning Innovation is a form of research that produces a learning model using applications that are easy to use. Latifah, Yuberti, and Agestiana (2020) through their research entitled "HOTS-Based Interactive Learning Media Development Using the Lectora Inspire Application" conclude that the Lectora Inspire application is valid to be used as a learning media tool. Hikmi, Simorangkir and Sudrajat (2020) state that multimedia is not just a tool to achieve goals of learning (Hariyoko et al., 2018). A new offer comes from a lectora inspire application that offers its users the ease of operating the application. The use of this application does not require a person who is truly an IT expert. The Lectore Inspire features an interface that is familiar to users who are familiar with and well versed in Microsoft Office (Mas'ud, 2014).

From some of the studies and theories that have been described, it can be concluded that IT-based media is needed in learning. IT-based learning will support the success of learning Pencak Silat by utilizing the lectora inspire application. Given the convenience that this application offers, it is necessary that the 
application is also used in the learning process of Pencak Silat to increase the variety of learning models that can be created easily.

Research on the learning model that will be applied to Pencak Silat focuses on refereeing material for students of Penjaskersek FKIP Universitas Riau. With the convenience that the application offers, it is hoped that it will be able to create an audio-visual based learning media for refereeing Pencak Silat that will be applied in the Lectora Inspire application. In addition, this study aims to develop lectora inspire that will be used in silat refinement during online learning.

\section{METHODS}

This study uses a research method or often referred to as Research \& Development. Research with this type of research and development uses steps according to Sugiyono (2013) includes: (1) Potentials and Problems, (2) Data collection, (3) Product Design, (4) Design Validation, (5) Product Revision, (6) Small Group Trials. In this study, researchers will carry out until small group trials considering the cost and time efficiency. The final study will be carried out by means of a feasibility test, a feasibility test in this study includes a quantitative descriptive statistical test.

The feasibility test is conducted by 1 media expert test by academics at the Universitas Riau, 1 material expert on duty at the Universitas Riau, and 10 application users by students of the Physical Education Study Program for Health and Recreation, Universitas Riau. The data obtained from these activities are used in the process of developing instructional media products in the form of quantitative data which is meant to be the observation of research results. The data collection instrument used is a questionnaire instrument in which there are several statements in order to be more systematic in obtaining data.

The analysis technique used is descriptive quantitative analysis techniques. Data analysis is taken for the first time using the observation method. After the observations are made, the researchers conduct statistical tests on the data obtained from the results of trials on media experts, material experts, and the results of trial subjects on health and recreational physical education students at the Universitas Riau. In connection with the results of validation and testing of products made, this study uses a Likert scale to determine the criteria from the results of trials to the subject. Further information can be seen in table 1 .

Table 1. Assessment Table

\begin{tabular}{ccc}
\hline No & Answer Options & Scores \\
\hline 1 & Excellent & 5 \\
2 & Good & 4 \\
3 & Fair & 3 \\
4 & Poor & 2 \\
5 & Bad & 1 \\
\hline
\end{tabular}

\section{RESULTS AND DISCUSSIONS}

The first step in this research starts from the potentials and problems. Potentials and problems have been described in the background of the problem by presenting several previous studies on learning media that have the potential to be used in the learning process of Pencak Silat, which then the authors analyze to look for possible problems to be resolved. Based on the results of the analysis on several previous research studies that try to create various instructional media products, the authors find several weaknesses. This weakness lies in the difficulty of teachers in making learning media and they still need IT experts for learning media. In line with this opinion, Budi and Prihanto (2014) explains that the development of learning media using IT-based media, namely audio-visual, is better than the use of print media. Agustiningsih (2015) reveals that in the development of learning media, it should pay attention to the development of science and technology so that it can be maximally delivered, compared to media that does not use science and technology.

Remembering multimedia is not just a tool used to achieve learning objectives, a new offering comes from a lectora inspire application that offers its users the ease of operating the application. The use of this application does not require a person who is truly an IT expert. The lectora inspire application is said to be a 
program that makes learning media easier. Remembering the ease with which it is offered, of course it is necessary to make variations in learning media using lectora inspire so that teachers can use it in the learning process of Pencak Silat refereeing.

Furthermore, the second stage is data collection. In more depth, the author tries to collect some references about lectora inspire. Some of these references consist of the results of research that has been carried out in order to create instructional media products using Lectora Inspire, from several references that the author gets, Lectora Inspire is indeed easy to use. It's just that, the use of lectora inspire has not been put to good use in the material of Pencak Silat refinement.

After the author tries to gather information through several literature reviews, the next step is product design. This product design is the initial product before consultation with experts. At this stage, the menus on the product cannot be accessed. The initial product in this study is similar to the product that has been through small group trials as shown in Figure 1, Figure 2, Figure 3, and Figure 4. The product that is designed, the writer consults the media and material experts. As for some of the product views developed by researchers after going through expert validation of material, media, and small group trials, they are as follows:

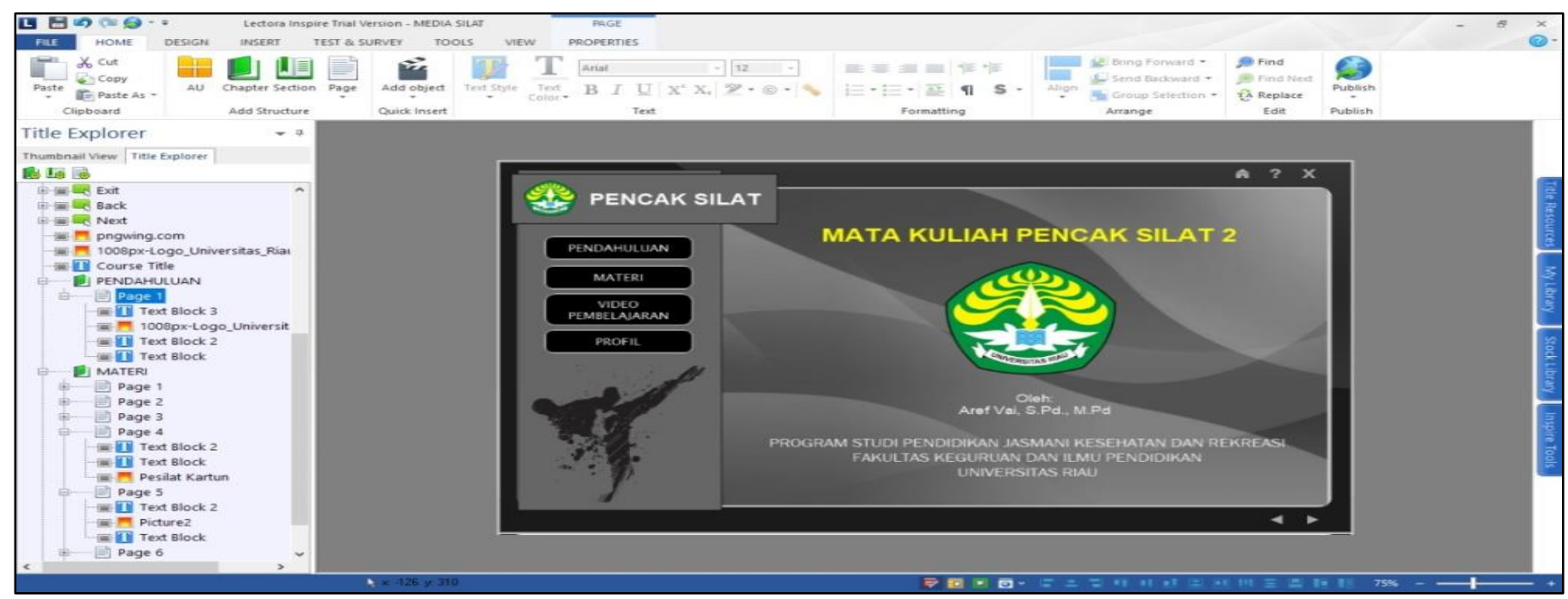

Figure 1. An Example of A Product Display on The Introduction Menu

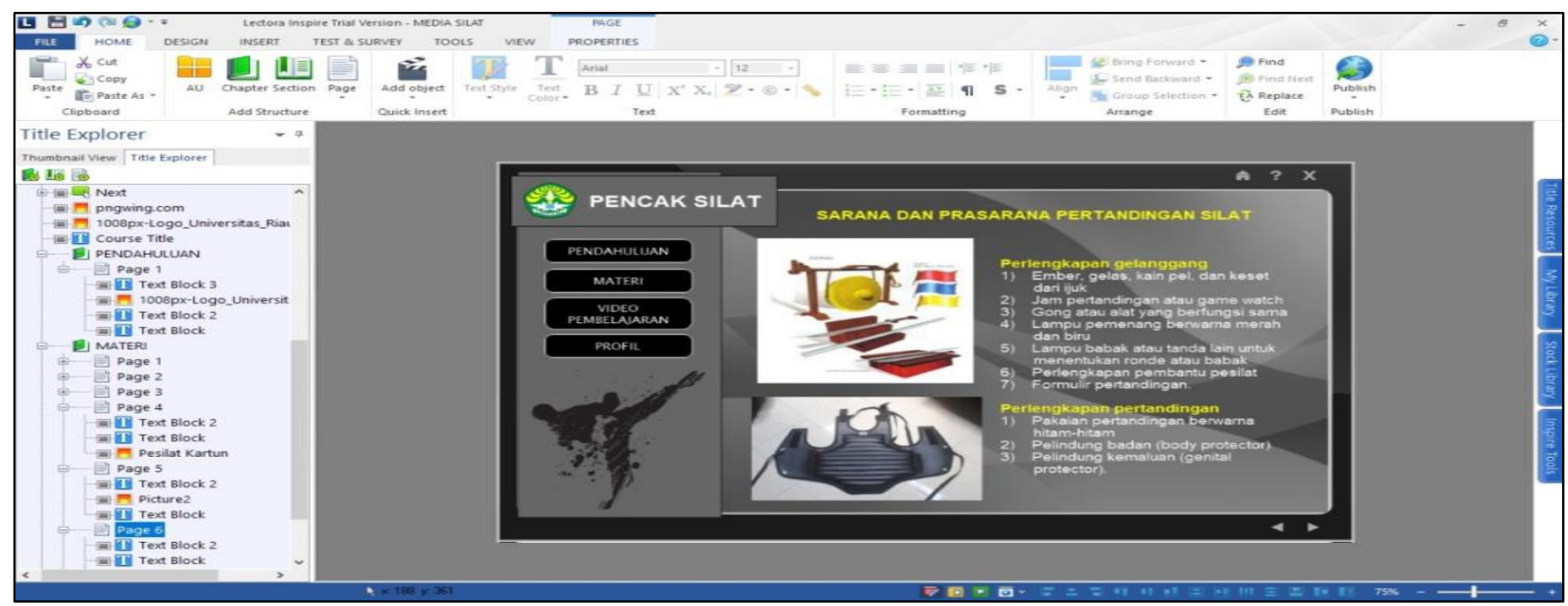

Figure 2. An Example of A Product Display on The Material Menu 


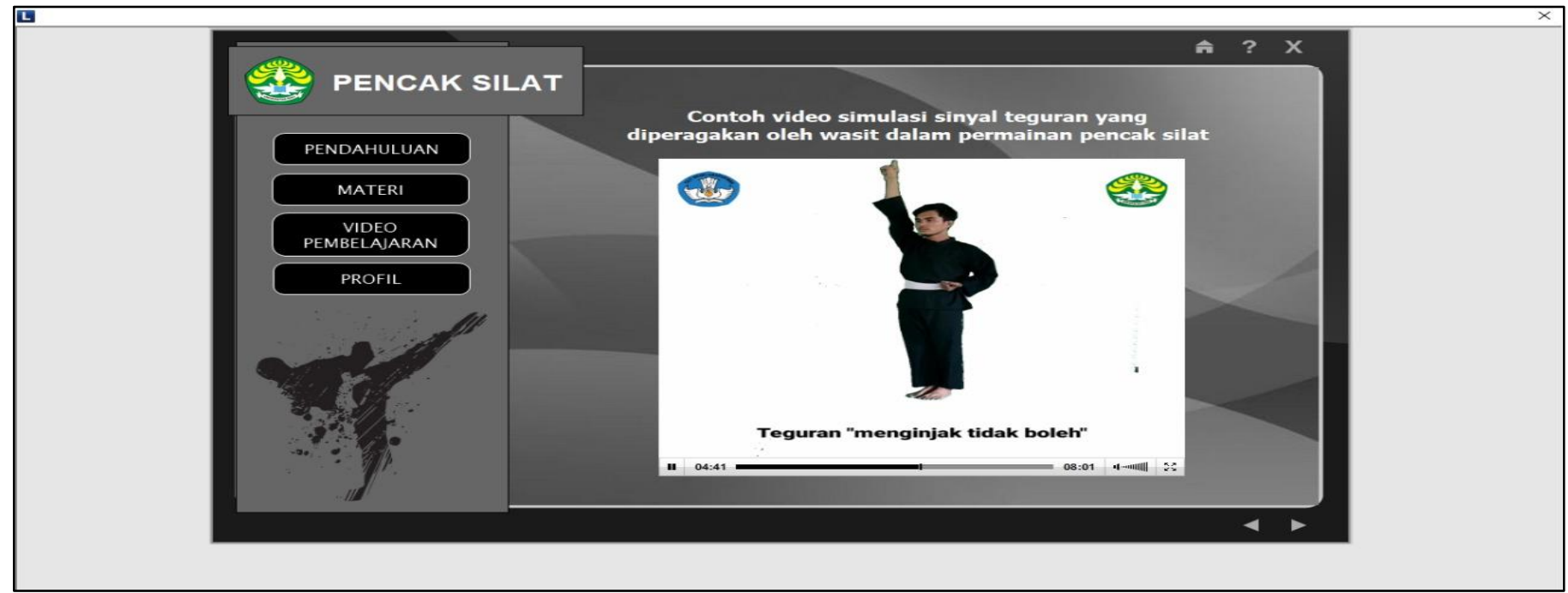

Figure 3. An Example of A Product Display on The Instructional Video Menu

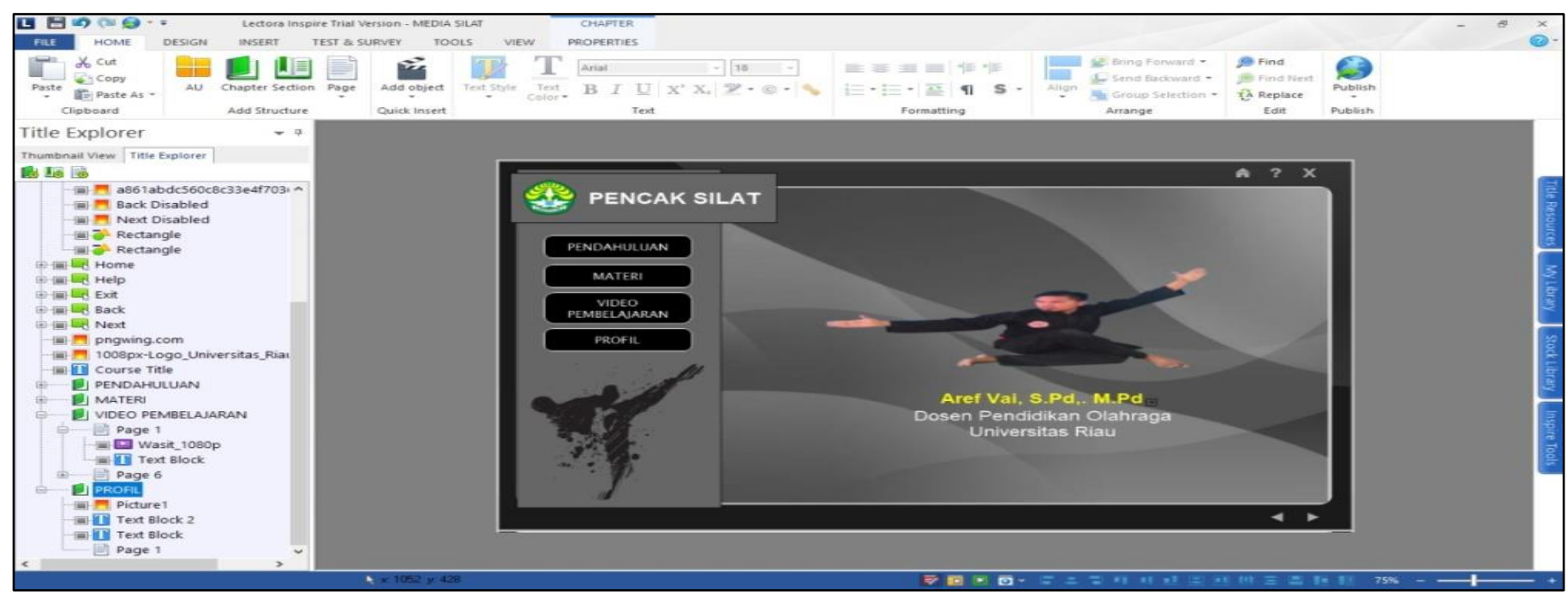

Figure 4. An Example of A Product Display on The Profile Menu

Based on the display in Figures 1, 2, 3, and 4, it can be seen that the menu available on the media that has been produced consists of an introduction menu, materials, learning videos, and profiles. The introductory menu contains the name of the course, the lecturer, and affiliation. Furthermore, the material menu contains theoretical material which will be studied by students in order to support theoretical knowledge before further understanding the practical activities of Pencak Silat refereeing on the learning video menu. The learning video menu is an embodiment of several theories that have been presented in the material menu. Finally, the profile menu contains the developer's biodata from the learning media of Pencak Silat refinement. The product display in Figures 1, 2, 3, and 4 is the result of the assessment of the validator and trials in small groups. With regard to the results of the assessment at the validation stage and small group trials, it can be seen in table 2 , table 3 , and table 4 .

Table 2. Material Expert Validation

\begin{tabular}{ccc}
\hline Rated Aspect & Average Scores & Criteria \\
\hline Content / Material Aspects & 4.23 & Good \\
Learning Aspects & 4.35 & Good \\
Average & 4.29 & Good \\
\hline
\end{tabular}

Data Primer, 2020 
It can be seen based on the results shown in table 2 above regarding the validation of material experts. If we observe from every aspect of content and material, the average score obtained is 4.23 and it is in the good category. Then, when viewed in the learning aspect, the score obtained is 4.35 and it is in the good category. For the average score, the overall value can be seen to get a score of 4.29 in the good category. Next, the results regarding the validation carried out for learning media can be seen in table 3 below:

Table 3. Media Validation of Silat Leaning

\begin{tabular}{ccc}
\hline Rated Aspects & Average Scores & Criteria \\
\hline Content / Material Aspects & 4,37 & Good \\
Aspects of Media & 4.32 & Good \\
Average & 4.34 & Good \\
\hline
\end{tabular}

Data Primer, 2020

Table 3 above reveals that the results obtained on the average score for the aspect of content or material aspects of 4.37 are in the good category. Then for the media aspect, it gets an average score of 4.32 which also gets a good category. For the overall score between the two aspects, it gets a score of 4.34 in the good category. After getting the results of the validation of tables 2 and 3 then the media is tested on a small scale which will be displayed in table 4 below:

Table 4. Small Group Trials

\begin{tabular}{ccc}
\hline Rated Aspects & Average Scores & Criteria \\
\hline Material / Content & 4,29 & Good \\
Media & 4.34 & Good \\
Average & 4.32 & Good \\
\hline
\end{tabular}

Data Primer, 2020

The results of the small-scale trial shown in Table 4 above obtain an average value of 4.29 in the material aspect or content with good categories. Furthermore, the media aspect gets an average score of 4.34 in the good category. While the average value as a whole includes aspects of material or content as well as media get an average value of 4.32 which can be categorized as good.

Learning media in many ways helps educators in exploring various abilities. Online learning not only makes it easier for educators to manage time, but also adds to the creativity of the individual. The lectora inspire application has the advantage of doing remote activities. This study aims to develop lectora inspire which will be used in Silat refinement during online learning. The rapid development of technology that occurs requires a teacher to be able to innovate not only to be fixated on conventional learning but also to be able to maximize technological progress (Kurniawan, Mujasam, Yusuf, \& Widyaningsih, 2019). The lectore inspire has good validity to use. Vidal-Abarca, Gilabert, Ferrer, Ávila, Martínez, Mañá, Llorens, Gil, Cerdán, Ramos, and Serrano (2014) reveal that learning using applications as a medium can improve learning outcomes, such applications are TuinLEC, PISA, Lectore Inspire. On the other hand, technology basically also helps someone in managing time management (Shaw, 2014) in the process of developing eleaning-based learning, it is hoped that it can facilitate the mastery of the material given to students. In line with this opinion, (Al-Alwani, 2014) reveals that the development of learning media carried out during Covid-19 must have the latest models that have an impact on teachers who must be able to explore the media that will be used in providing learning.

The phenomenon that is happening now is that many teachers have used YouTube, Zoom, Google Meet, and so on as a medium in the learning process. As we know, the teacher's inability to utilize the media will have an impact on boredom in the learning process, as a result, less attractive learning, and even less attractive media lead to less effective learning. According to Inner Burner (Azhar, 2007) says there are three levels of learning mode, namely direct experience (anactive), pictorial experience (iconic), and abstract experience (symbolic). Several studies have been carried out that using media in the learning process will be able to increase students' interest in learning so that learning runs effectively, because the media has a number of advantages that can be used to increase interest and the effectiveness of learning. According to 
Widiantoro and Rakhmawati (2015) web-based learning benefits educators and students because it can be used anytime without being bound by time and space. According to Azhar (2007) media is a component of learning resources or physical vehicles that contain instructional material in the student environment that can stimulate student learning. In e-learning itself, understanding how the learning and teaching process is the most important thing in learning the dimensions of e-leaning (Terras \& Ramsay, 2014).

The development of lectora inspire-based media in the refereeing material of Pencak Silat is designed to be used as a learning medium for Pencak Silat where the process goes through a development research process starting from the planning, making, and assessment/evaluation process. Products developed are using one of the interactive learning applications, namely the Lectora Inspire application. Products that have been developed will be validated by experts. Based on the results of the data that has been obtained through the validation test, the learning indicators are categorized as good with a mean score of 4.35 . Then on the indicator of refereeing material in the good category the average score is 4.23 . The assessment criteria for the learning indicators are at a percentage of $85 \%$ in the good category, and the material indicators are at $80 \%$ in the good category. In the following, the data on the assessment of the material quality of the assessment results are obtained in table 1.

The next process after the material has been validated is continued with the creation of media by recording a model that displays the movements of the referee's symbols in special Pencak Silat in the competition category. Then the editing process is carried out and converted to the Lectora Inspire application, then tested for validation by a media expert. After going through the revision, the evaluation is carried out so that the rating is obtained with an average of 4.32 with a good category display indicator. Then the indicator of the programming aspect is good category at an average of 4.37. Based on the data obtained from 21 statement items on the display indicators relating to the excellence of the resulting media, a percentage of $73.70 \%$ is obtained and categorized as good and programming indicators related to the superiority of the resulting media, $80 \%$ data is very good category. The quality of learning media products results from validation of media experts through the process of distributing questionnaires. The following shows the media quality assessment data obtained from the results of the assessment in table 2 . The quality of the product of an audio-visual based learning media for refereeing Pencak Silat using the Lectora Inspire application can be seen in table 3 .

The development of refereeing learning media in Pencak Silat with lectora inspire-based audio-visual media has gone through a validation testing process carried out with the aim of whether refereeing learning media in Pencak Silat with lectora inspire-based audio-visual media is feasible or not suitable for use in the learning process. It is necessary to note that the development of this product has not yet reached the perfect stage because the test results are only limited to material and appearance validation tests and have not been tested in large groups, therefore there is a need for further development.

Various efforts are made to create an interactive learning process. This can be seen from various studies that have resulted in IT-based learning models such as those conducted by Vai et., (2019) regarding Media Development in Learning Pencak Silat for Senior High School level based on multimedia. The research results in an IT-based learning model. The software used in the process of making this learning model is Adobe Flash CS. In addition, research on other IT-based Pencak Silat learning models with the title Media Development utilizing macromedia flash 8 in Learning-based Pencak Silat for Junior High Schools has also been conducted (Valentino \& Ihsan, 2018). The research results in a product in the form of a CD of Interactive Multimedia learning media using the Macromedia Flash 8 application on the subject of PJOK, grade VIII class of Pencak Silat material.

Other research is also carried out by Oktavianingtyas, Salama, Fatahillah, Monalisa, and Setiawan (2018) in that the study concluds that the use of technology in learning can improve skills. In this study, the selection of Adobe Flash CS5 is possible because it can create interactive learning media, complete features and the developed media is able to actively engage students' senses of sight and hearing which causes maximum understanding of the material. Furthermore, Rohmatika (2015) also conducts research on learning media to produce multimedia-based Origami learning media application products. In Palelupu and Cholik research (2014), development is also carried out by utilizing Adobe Flash CS5 in the technical drawing 
training eye. However, from several previous studies, the use of lectora has advantages in its ease of use. Lectora inspire has advantages that can make learning more effective (Nursidik \& Suri, 2018). Lectora Inspire software can be used as an alternative in choosing media to create learning activities that are easy for the teacher, interactive for students and students and with a good level of material absorption.

The implication of research based on theoretical studies and empirical studies will have an impact on student learning because learning can have a positive impact on students and for others, as student motivation in participating in learning and teacher motivation in creating, developing and using learning media.

\section{CONCLUSION}

Based on the results of the data analysis carried out, it can be concluded that the Lectora Inspire application is suitable for use as an audio-visual based Pencak Silat learning medium on a small group test scale. This research is conducted only until a small-scale trial, considering that this is the first time this Lectora Inspire has been conducted in a Pencak Silat course. The results of this study are to add references and insights for academics, practitioners, and students in developing Lectora Inspire. The limitation in this study is that the variables are used a little so it is necessary to add more research variables. Furthermore, to further test the effectiveness of this product so that it can be used on a broader scale, researchers should conduct research up to large-scale trials and up to the product marketing process stage.

\section{REFERENCES}

Agustiningsih, A. (2015). Video Sebagai Alternatif Media Pembelajaran Dalam Rangka Mendukung Keberhasilan Penerapan Kurikulum 2013 di Sekolah Dasar. PEDAGOGIA: Jurnal Pendidikan, 4(1), 50. https://doi.org/10.21070/pedagogia.v4i1.72

Al-Alwani, A. (2014). Evaluation criterion for quality assessment of E-learning content. E-Learning and Digital Media, 11(6), 532-542. https://doi.org/10.2304/elea.2014.11.6.532

Azhar, A. (2007). Media Pembelajaran. Jakarta: PT. Raja Grafindo Persada.

Budi, B. A. S., \& Prihanto, J. B. (2014). Penggunaan media audiovisual dengan media gambar terhadap hasil belajar shooting bola basket (Studi pada siswa kelas VIII SMP Negeri 1 Jatiroto Kabupaten Lumajang ). Jurnal Ilmiah Pendidikan Jasmani Olahraga dan Kesehatan, 2(3), 612-616.

Cecep, K., \& Bambang, S. (2011). Media Pembelajaran Manual dan Digital. Bogor: Ghalia Indonesia.

Doloksaribu, F. E., \& Triwiyono, T. (2020). The reconstruction model of science learning based phetproblem solving. International Journal on Studies in Education, 3(1), 37-47. https://doi.org/10.46328/ijonse.30

Estheria, N. G. N., \& Muhid, A. (2020). Pengembangan kreativitas berpikir siswa di era industri 4.0 melalui perangkat pembelajaran dengan media augmented reality. Insight: Jurnal Ilmiah Psikologi, 22(2), 118129. https://doi.org/10.26486/psikologi.v22i2.1206

Hariyoko., Hariyanto, E., \& Kurniawan, A. W. (2018). Pengembangan Media Audio-Visual Pencak Silat Seni Dengan Musik. Gelanggang Pendidikan Jasmani Indonesia, 2(1), 10. https://doi.org/10.17977/um040v2i1p10-17 
Hikmi, R., Simorangkir, M., \& Sudrajat, A. (2020). Development of interactive multimedia lectora inspire problem based on science. Journal of Physics: Conference Series, 1485(1). https://doi.org/10.1088/1742-6596/1485/1/012036

Hussin, A. A. (2018). Education 4.0 made simple: Ideas for teaching. International Journal of Education and Literacy Studies, 6(3), 92-98. http://dx.doi.org/10.7575/aiac.ijels.v.6n.3p.92

Iswana, B., \& Siswantoyo, S. (2013). Model latihan keterampilan gerak pencak silat anak usia 9-12 tahun. Jurnal Keolahragaan, 1(1), 26-36. https://doi.org/10.21831/jk.v1i1.2343

Kurniawan, R. B., Mujasam, M., Yusuf, I., \& Widyaningsih, S. W. (2019). Development of physics learning media based on Lectora Inspire Software on the elasticity and Hooke's law material in senior high school. Journal of Physics: Conference Series, 1157(3). https://doi.org/10.1088/1742$6596 / 1157 / 3 / 032022$

Latifah, S., Yuberti, Y., \& Agestiana, V. (2020). Pengembangan Media Pembelajaran Interaktif Berbasis Hots Menggunakan Aplikasi Lectora Inspire. Jurnal Penelitian Pembelajaran Fisika, 11(1), 9. https://doi.org/10.26877/jp2f.v11i1.3851

Mas’ud, M. (2014). Membuat Multimedia Pembelajaran dengan Lactora. Yogyakarta: Pustaka Shonif.

Nursidik, H., \& Suri, I. R. A. (2018). Media Pembelajaran Interaktif Berbantu Software Lectora inspire. Desimal: Jurnal Matematika, 1(2), 237. https://doi.org/10.24042/djm.v1i2.2583

Oktavianingtyas, E., Salama, F. S., Fatahillah, A., Monalisa, L. A., \& Setiawan, T. B. (2018). Development 3D Animated Story as Interactive Learning Media with Lectora Inspire and Plotagon on Direct and Inverse Proportion Subject. Journal of Physics: Conference Series, 1108(1). https://doi.org/10.1088/1742-6596/1108/1/012111

Palelupu, D. N., \& Cholik, M. (2014). Pengembangan Media Pembelajaran Berbasis Adobe Flash CS5 Pada Mata Diklat Gambar Teknik Di Kelas X TPM SMK Krian 1 Sidoarjo. Jurnal Pendidikan Teknik Mesin, 3(2), 10-19.

Rahmatullah, M. I. (2019). Pengembangan Konsep Pembelajaran Literasi Digital Berbasis Media ELearning Pada Mata Pelajaran PJOK di SMA Kota Yogyakarta. Journal Of Sport Education (JOPE), 1(2), 56. https://doi.org/10.31258/jope.1.2.56-65

Rohmatika, E. (2015). Aplikasi Media Pembelajaran Origami Berbasis Flash Menggunakan Adobe Flash Cs5. Thesis. Universitas Negeri Yogyakarta.

Saputro, N. V., Masturi, \& Supriyadi. (2020). The effectiveness of instructional media based on lectora inspire towards student's achievement. Journal of Physics: Conference Series, 1567(2), 4-10. https://doi.org/10.1088/1742-6596/1567/2/022063

Sardirman, A. S. (2019). Media Pendidikan: Pengertian, Pengembangan dan Pemanfaatannya. Jakarta: Raja Grafindo Persada.

Shaw, R. (2014). Heidegger and e-learning: Overthrowing the traditions of pedagogy. E-Learning and Digital Media, 11(2), 123-134. https://doi.org/10.2304/elea.2014.11.2.123 
Sugiyono. (2013). Metode Penelitian Kualitatif. Bandung: Alfabeta.

Terras, M. M., \& Ramsay, J. (2014). A psychological perspective on the temporal dimensions of e-learning. E-Learning and Digital Media, 11(2), 108-122. https://doi.org/10.2304/elea.2014.11.2.108

Vai, A., Ramadi., Juita, A., \& Sulaastio, A. (2019). The Media Development of Pencak Silat Learning Multimedia Based at SMA/MA. Advances in Social Science, Education and Humanities Research, 362(Acpes), 178-182. https://doi.org/10.2991/acpes-19.2019.40

Valentino, R., \& Ihsan, N. (2018). Pengembangan Media Pembelajaran Pencak Silat Berbasis Macromedia Flash 8 Untuk Sekolah Menengah Pertama. Jurnal Pendidikan dan Olahraga, 1(1), 23-24.

Vidal-Abarca, E., Gilabert, R., Ferrer, A., Ávila, V., Martínez, T., Mañá, A., Llorens, A. C., Gil, L., Cerdán, R., Ramos, L., \& Serrano, M. Á. (2014). TuinLEC, an intelligent tutoring system to improve reading literacy skills / TuinLEC, un tutor inteligente para mejorar la competencia lectora. Infancia $y$ Aprendizaje, 37(1), 25-56. https://doi.org/10.1080/02103702.2014.881657

Widiantoro, B., \& Rakhmawati, L. (2015). Pengembangan media pembelajaran e-learning berbasis schoology pada kompetensi dasar di SMKN 1 Jetis. Jurnal Pendidikan Teknik Elektro, 4(2), 501-506. 